\title{
Technical note: Milk composition in mice-Methodological aspects and effects of mouse strain and lactation day
}

\author{
S. Görs, ${ }^{*}$ M. Kucia, ${ }^{*}$ M. Langhammer,† P. Junghans, ${ }^{*}$ and C. C. Metges ${ }^{\star 1}$ \\ *Nutritional Physiology "Oskar-Kellner", and \\ †Genetics and Biometry, Research Institute for the Biology of Farm Animals (FBN), D-18196 Dummerstorf, Germany
}

\begin{abstract}
Analysis in individual mouse milk samples is restricted by small sample volumes and hindered by high fat contents. Miniaturized methods were developed for the analysis of dry matter (DM), crude fat, crude protein $(\mathrm{CP})$, and lactose in individual samples of $\leq 200 \mu \mathrm{L}$ of fresh or previously frozen mouse milk and used to compare milk from the mouse strain DU6, the largest growth-selected mouse line worldwide, with unselected mice $(\mathrm{CON})$ on lactation d 3, 14, and 18 . Individual milk samples were collected by means of a self-constructed milking machine. Aliquots of $10 \mu \mathrm{L}$ of milk were used to measure DM [coefficient of variation $(\mathrm{CV})<2.1 \%$ ], which was subsequently used to analyze nitrogen for calculation of CP (CV 2.7\%). Crude fat was determined in $100 \mu \mathrm{L}$ via a miniaturized RöseGottlieb method (CV 2.8\%). An HPLC protocol was used to analyze lactose in $20 \mu \mathrm{L}$ of diluted whey (CV $5.3 \%)$. The miniaturized methods gave similar results compared with conventional approaches. Homogenization was the most important factor affecting milk composition and its reproducibility. Milk storage at $-20^{\circ} \mathrm{C}$ had no effect on composition. Irrespective of the mouse strain, maximum values of $45.5 \% \mathrm{DM}, 29.8 \%$ fat, and $12.7 \% \mathrm{CP}$ were observed at $\mathrm{d} 14$. The greatest lactose contents were found on d $18(2.41 \%)$. Milk lactose concentration at d 3 was lower in DU6 $(1.13 \pm 0.10 \%)$ than CON $(1.67 \pm 0.18 \%)$. The method provides an accurate assessment of mouse milk composition.
\end{abstract}

Key words: mouse milk composition, small sample volume, lactose, high-performance liquid chromatography

Analysis of mouse milk is challenging because of the small sample volume available and the high fat content. Thus, individual mouse milk samples are usually pooled from several dams, or over several lactation days, or both, to yield a sufficient analytical sample (Knight

Received July 18, 2008.

Accepted October 2, 2008.

${ }^{1}$ Corresponding author: metges@fbn-dummerstorf.de et al., 1986), thereby losing information on composition variability. Various methods have been applied for protein and fat composition analysis of mouse milk. Milk protein was determined via various colorimetric approaches (Ragueneau, 1987) because of the low milk volume necessary. Also, the Kjeldahl method was applied as used for cow's milk (Knight et al., 1986). Fat was analyzed gravimetrically using the Bligh and Dyer extraction procedure with methanol/chloroform (Rath and Thenen, 1979), by the Röse-Gottlieb method (Ragueneau, 1987), or the "creamatocrit" determination for low sample volumes based on the Fleet and Linzell approach (Knight et al., 1986). Typically, lactose in mouse milk is determined enzymatically after hydrolysis to yield glucose and galactose and subsequent analysis of one of these monomers (Riley et al., 2006). Our objective was to develop miniaturized methods for the complete analysis of DM, fat, CP, and lactose in 1 sample of $\leq 200 \mu \mathrm{L}$ of fresh and previously frozen mouse milk. Of interest was the milk composition of the mouse strain DU6, which is the largest growth-selected mouse line worldwide (Bünger et al., 2001; Renne et al., 2006). The hypothesis was that milk of this strain was rich in macronutrients to support the rapid growth of mouse pups.

Female virgin mice from 2 strains (selected in the long term for high BW: DU6, $\mathrm{n}=23$; unselected control: CON, $\mathrm{n}=25$; of strain DUK; Bünger et al., 2001) bred in Dummerstorf were obtained from the Institute's mouse facility and mated ( 1 female: 1 male) at age 63 $\pm 10 \mathrm{~d}$. At the time of mating, the BW of DU6 females $(64.4 \pm 6.9 \mathrm{~g})$ was $>2$ times that of CON $(30.2 \pm 2.5$ g). Pregnant dams were housed individually in Macrolon cages Type II (Ebeco, Castrop-Rauxel, Germany) with sawdust bedding at $21^{\circ} \mathrm{C}$ with a $12: 12 \mathrm{~h}$ dark:light cycle. The feed was semisynthetic and contained $20 \%$ casein supplemented with $0.8 \%$ DL-methionine, $60 \%$ starch and sugar, and 5\% soy oil and microcellulose, as well as appropriate vitamin and mineral mixtures (SNIFF Spezialdiät GmbH, Soest, Germany). Feed was supplied ad libitum and met or exceeded requirements for breeding mice. Animals had free access to water. After parturition all litters were standardized 
to 10 pups at the day of birth. At lactation d 3, 14, and 18, dams were separated from their pups for $3 \mathrm{~h}$, anesthetized by subcutaneous injection of a mixture of ketamine-HCl $(87 \mathrm{mg} / \mathrm{kg}$ of BW, Ursotamin, SerumWerk-Bernburg AG, Bernburg, Germany) and xylazine $(13 \mathrm{mg} / \mathrm{kg}$ of BW, xylazine 2\%, Riemser Arzneimittel AG, Greiswald, Insel Riems, Germany). Subsequently, they were injected with $0.1 \mathrm{~mL}$ of oxytocin s.c. (10 IU/ mL, Oxytocin Bengen, WdT eG, Garbsen, Germany), and their mammary glands were massaged slightly to induce milk letdown. The dams were milked using a milking machine self-constructed with modifications as described previously (Rodgers, 1995). It consists of an electronic controller connected to a pump (KNF Neuberger Lab Laboport, Freiburg, Germany) producing a low pulsatory vacuum (0.5-s pulses, $60 / \mathrm{min})$ to imitate the sucking stimulus. A 1-mL syringe (Omnifix, Brand, Germany) was used as the collecting vessel. All teats of each dam were repeatedly milked for a total period of 10 to 15 min. Milk sample volumes collected ranged between $100 \mu \mathrm{L}$ and $0.5 \mathrm{~mL}$ per mouse. Samples $<200$ $\mu \mathrm{L}$ were pooled. A total of 20 and 23 milk samples were obtained from CON and DU6 dams, respectively. To compare fresh and frozen milk, a subset of 5 CON dams was fed a standard rodent chow ad libitum (Altromin 1314, Altromin GmbH, Lage, Germany; 22.5\% CP, $5 \%$ crude fat, $12.5 \mathrm{MJ}$ of $\mathrm{ME} / \mathrm{kg}$ of $\mathrm{DM})$. Dams were milked at lactation d 14 and 19 following the procedure described. Equal volumes $(500 \mu \mathrm{L})$ of milk from every 2 of 4 animals were pooled and split into 2 portions. One sample was analyzed immediately, the other after storage for $7 \mathrm{~d}$ at $-20^{\circ} \mathrm{C}$.

Method development was carried out with carrageenan-free sweet cream (30\% fat; BioGreno Naturkost,

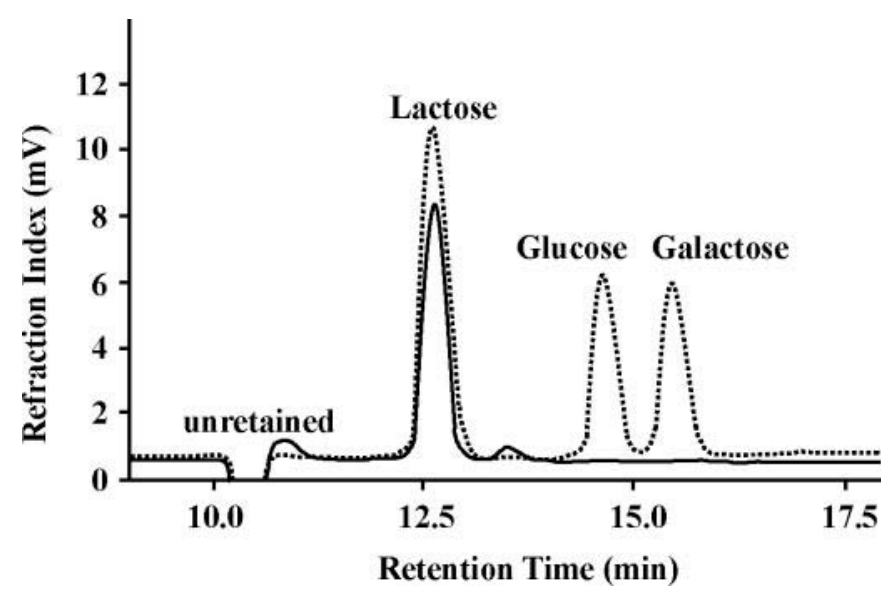

Figure 1. Intensity of refraction index signals $(\mathrm{mV})$ versus retention times (min) after HPLC separation of $2 \mathrm{~m} M$ saccharide standards (lactose $12.6 \mathrm{~min}$, glucose $14.6 \mathrm{~min}$, galactose $15.4 \mathrm{~min}$, dotted line) and 50-fold diluted mouse milk whey (control strain, d 18, solid line).
Gebrüder Rogge, Gronau, Germany), raw cow's milk $(<4 \%$ fat $)$, and a mixture thereof with approximately $17 \%$ fat. Milk model mixtures were stored in the same way as the mouse milk. Fresh and defrosted samples were homogenized by gently stirring or pivoting.

The DM content was measured in duplicate in 10 $\mu \mathrm{L}$ of milk filled in a precombusted and preweighed tin capsule $(3.3 \times 5 \mathrm{~mm}$, Säntis Analytical, Teufen, Switzerland). After weighing the samples were dried at $55^{\circ} \mathrm{C}$ for $5 \mathrm{~h}$, cooled to room temperature, and DM was determined. The intraassay CV (precision) for triplicates was usually $<2.1 \%$. The method was verified in $50 \mu \mathrm{L}$ of milk dried at $60^{\circ} \mathrm{C}$ for $1 \mathrm{~h}$ and $105^{\circ} \mathrm{C}$ for $3 \mathrm{~h}$ (Wiessmann and Nehring, 1951) in glass dishes or at $55^{\circ} \mathrm{C}$ for $5 \mathrm{~h}$ in $2-\mathrm{mL}$ glass vials (Table 1 ). The $\mathrm{CP}$ content was calculated from duplicate nitrogen determinations $(\mathrm{N} \times 6.38$; Knight et al., 1986) performed in the same tin capsules as used for DM determination. They were closed airtight and converted in an elemental analyzer (EA 1108, Fisons Instr., Rodano Milan, Italy) to $\mathrm{N}_{2}$, which was determined by mass spectrometry (delta $\mathrm{S}$ interfaced to ConFlo II, Finnigan MAT, Bremen, Germany). The precision for triplicate measurements was 0.1 to $6.7 \%$ (mean CV 2.7\%).

Crude fat was determined by a miniaturized version of the Röse-Gottlieb method. In 15-mL precombusted $\left(550^{\circ} \mathrm{C}, 4 \mathrm{~h}\right)$ glass tubes, $100-\mu \mathrm{L}$ aliquots of mouse milk were diluted with $900 \mu \mathrm{L}$ of water. Subsequently, 200 $\mu \mathrm{L}$ of concentrated $\mathrm{NH}_{3}$ (25\%), $1 \mathrm{~mL}$ of ethanol, $3 \mathrm{~mL}$ of diethyl ether, $3 \mathrm{~mL}$ of petroleum ether (boiling point 30 to $50^{\circ} \mathrm{C}$ ), and $800 \mu \mathrm{L}$ of water were added, and each time the mixture was shaken vigorously for $30 \mathrm{~s}$. After complete separation, the upper layer was measured. A volume of $4 \mathrm{~mL}$ of this lipid layer was transferred into a precombusted and preweighed glass vial and evaporated in a nitrogen stream. The residue was dried for 2 $\mathrm{h}$ at $105^{\circ} \mathrm{C}$, cooled, and weighed. The fat content was calculated as follows:

$$
\begin{gathered}
\text { Fat, } \%=[\text { net weight from } 4 \mathrm{~mL} \text { of evaporated } \\
\text { lipid layer }(\mathrm{g}) \times 5] \\
\times[\text { volume of lipid layer }(\mathrm{mL}) \times 5] \\
\quad \times(\text { factor of dilution } 10) .
\end{gathered}
$$

Triplicate measurements of fat had a precision of $<2 \%$ for milk model mixtures and 0.8 to $6.6 \%$ for mouse milk, respectively (mean CV 2.8\%). Results were verified in a 3- to 4-g milk model mixture by a reference laboratory (Qualitätsprüfungs und Dienstleistungsgesellschaft Mecklenburg-Vorpommern mbH, Güstrow, Germany) using the Röse-Gottlieb reference method (Table 1). 
Table 1. Dry matter, crude fat, and lactose (mean $\pm \mathrm{SD}, \mathrm{n}=3$ ) in model milk mixtures and mouse milk using different analytical procedures

\begin{tabular}{|c|c|c|c|c|c|c|c|c|c|c|}
\hline \multirow[b]{2}{*}{ Sample } & \multicolumn{4}{|c|}{$\mathrm{DM}, \%$} & \multicolumn{3}{|c|}{ Crude fat, $\%$} & \multicolumn{3}{|c|}{ Lactose, $\%$} \\
\hline & $\begin{array}{c}\text { Glass dish; } \\
50 \mu \mathrm{L} \text { of milk; } \\
60 / 105^{\circ} \mathrm{C} ; 1 / 3 \mathrm{~h}^{1}\end{array}$ & $\begin{array}{l}\text { Glass vial; } \\
50 \mu \mathrm{L} \text { of milk; } \\
55^{\circ} \mathrm{C} ; 5 \mathrm{~h}\end{array}$ & $\begin{array}{l}\text { Tin cup; } \\
10 \mu \mathrm{L} \text { of milk; } \\
55^{\circ} \mathrm{C} ; 5 \mathrm{~h}\end{array}$ & $P$-value & $\begin{array}{l}\text { Miniaturized } \\
\text { Röse-Gottlieb }\end{array}$ & $\begin{array}{c}\text { Reference } \\
\text { Röse-Gottlieb }\end{array}$ & $P$-value & $\begin{array}{l}\text { HPLC } \\
\text { method }\end{array}$ & $\begin{array}{l}\text { Enzymatic } \\
\text { method }^{2}\end{array}$ & $P$-value \\
\hline Sweet cream $^{3}$ & $35.6 \pm 1.88$ & $35.3 \pm 0.53$ & $36.0 \pm 0.68$ & 0.62 & $28.24 \pm 0.10$ & $29.26 \pm 0.04$ & 0.03 & $3.38 \pm 0.17$ & $3.32 \pm 0.02$ & 0.61 \\
\hline Model mixture $^{4}$ & $24.1 \pm 0.25$ & $24.3 \pm 0.46$ & $24.6 \pm 0.36$ & 0.37 & $16.74 \pm 0.13$ & $17.20 \pm 0.05$ & 0.02 & $3.81 \pm 0.01$ & $3.94 \pm 0.03$ & 0.01 \\
\hline Raw cow's milk ${ }^{5}$ & $12.9 \pm 0.11$ & $13.0 \pm 0.15$ & $13.0 \pm 0.05$ & 0.43 & $3.83 \pm 0.07$ & $3.89 \pm 0.00$ & 0.30 & $4.71 \pm 0.30$ & $4.67 \pm 0.02$ & 0.84 \\
\hline Mouse milk ${ }^{6}$ & $35.2 \pm 0.24$ & $34.9 \pm 0.57$ & $36.4 \pm 0.75$ & 0.22 & & & & & & \\
\hline
\end{tabular}

$8{ }^{1}$ Sample was dried first at $60^{\circ} \mathrm{C}$ for $1 \mathrm{~h}$ and then at $105^{\circ} \mathrm{C}$ for $3 \mathrm{~h}$.

${ }^{2}$ Commercial reference laboratory (Qualitätsprüfungs und Dienstleistungsgesellschaft Mecklenburg-Vorpommern mbH, Güstrow, Germany).

${ }^{3}$ BioGreno Naturkost, Gebrüder Rogge (Gronau, Germany).

${ }^{4}$ Sweet cream: raw cow's milk $(1: 1$, vol/vol).

${ }^{5}$ Derived from FBN dairy herd (Dummerstorf, Germany).

${ }^{6}$ Mouse no. 40 of DU6 strain, lactation d 18.

Table 2. Constituents (mean $\pm \mathrm{SD}, \mathrm{n}=3)$ in fresh and frozen $\left(-20^{\circ} \mathrm{C}\right)$ pooled mouse milk $(2$ mice per pool) of the control strain

\begin{tabular}{|c|c|c|c|c|c|c|c|c|c|c|c|c|}
\hline \multirow[b]{3}{*}{ Item } & \multicolumn{6}{|c|}{ Lactation d 14} & \multicolumn{6}{|c|}{ Lactation d 19} \\
\hline & \multicolumn{3}{|c|}{ Pool 1} & \multicolumn{3}{|c|}{ Pool 2} & \multicolumn{3}{|c|}{ Pool 1} & \multicolumn{3}{|c|}{ Pool 2} \\
\hline & Fresh & Frozen & $P$-value & Fresh & Frozen & $P$-value & Fresh & Frozen & $P$-value & Fresh & Frozen & $P$-value \\
\hline $\mathrm{DM}, \%$ & $37.8 \pm 0.24$ & $34.9 \pm 3.93$ & 0.34 & $37.3 \pm 0.09$ & $37.3 \pm 4.48$ & 1.00 & $36.3 \pm 0.36$ & $36.0 \pm 0.39$ & 0.41 & $39.5 \pm 0.33$ & $39.4 \pm 0.08$ & 0.73 \\
\hline $\mathrm{CP}, \%$ & $12.7 \pm 0.29$ & $13.5 \pm 0.66$ & 0.17 & $12.6 \pm 0.42$ & $13.8 \pm 0.79$ & 0.09 & $10.1 \pm 0.57$ & $10.3 \pm 0.69$ & 0.65 & $10.9 \pm 0.01$ & $10.8 \pm 0.09$ & 0.10 \\
\hline Crude fat, $\%$ & $20.1 \pm 0.63$ & $19.3 \pm 0.16$ & 0.06 & $19.3 \pm 0.34$ & $19.7 \pm 0.79$ & 0.51 & $20.8 \pm 0.75$ & $20.8 \pm 1.19$ & 0.97 & $22.9 \pm 0.62$ & $22.8 \pm 1.50$ & 0.92 \\
\hline Lactose, $\%$ & $2.43 \pm 0.25$ & $2.49 \pm 0.08$ & 0.49 & $2.37 \pm 0.21$ & $2.46 \pm 0.04$ & 0.42 & $2.84 \pm 0.10$ & $2.84 \pm 0.25$ & 0.99 & $2.76 \pm 0.14$ & $2.71 \pm 0.16$ & 0.67 \\
\hline
\end{tabular}


Additionally, fat was analyzed by the creamatocrit method using a hematocrit centrifuge (Mikro 22 R, Hettich Zentrifugen, Tuttlingen, Germany; Knight et al., 1986).

For lactose determination, aliquots of 20 to $30 \mu \mathrm{L}$ of mouse milk were diluted by a factor of 5 with water and centrifuged at $50,000 \times g$ for $20 \mathrm{~min}$ at $4^{\circ} \mathrm{C}$. The diluted whey was stored at $-20^{\circ} \mathrm{C}$. The samples were thawed and diluted by a factor of 10 , sonicated for $2 \mathrm{~min}$, and centrifuged at $16,100 \times g$ for $10 \mathrm{~min}$ at $4^{\circ} \mathrm{C}$. Twenty microliters of the clear diluted whey was separated isocratically by HPLC [degasser Degasys DG-1310, Uniflows, Tokyo, Japan; autosampler Marathon XT, pump Pharmacia LKB 2248, both Pharmacia Biotech, Uppsala, Sweden; column thermostat, W. O. Electronics, Langenzersdorf, Austria; refraction index detector Smartline 2300, Knauer, Berlin, Germany] on a Rezex ROA-Organic Acid column $(300 \times 7.8 \mathrm{~mm}$ i.d., $8 \mu \mathrm{m}$; Phenomenex, Aschaffenburg, Germany) protected with a Carbo- $\mathrm{H}^{+}$guard cartridge $(4 \times 3 \mathrm{~mm}$ i.d., Phenomenex) by a flow of $0.4 \mathrm{~mL} / \mathrm{min}$ with $5 \mathrm{mM}$ $\mathrm{H}_{2} \mathrm{SO}_{4}$ at $75^{\circ} \mathrm{C}$ (Karsten et al., 2005). Lactose, glucose, and galactose were quantified by a 3-point calibration with external standards (Figure 1). The detection limit was $50 \mu M$. Lactose concentration (\%) was converted after correction for milk fat. The precision for triplicate determinations ranged from 0.6 to $10.3 \%$ (CV; mean $5.3 \%)$. Lactose values determined by HPLC were verified enzymatically by the reference laboratory (Qualitätsprüfungs und Dienstleistungsgesellschaft Mecklenburg-Vorpommern $\mathrm{mbH}$ ) in 3-g milk model mixture. All chemicals were of analytical grade.

Results are presented as means \pm standard deviations for analytical replicates and means \pm standard error of mean for variables compared between mouse strains. Data were analyzed by SPSS 15 (SPSS Inc., Chicago, IL) performing a 1-way ANOVA for effects of the analytical method and 2-way ANOVA for effects of lactation day and strain, followed by a post-hoc TukeyHonestly Significantly Different test. Significance was defined at $P \leq 0.05$.

Irrespective of the method used, DM content of mouse milk model mixtures showed similar results. Fat contents $\geq 16 \%$ measured by the miniaturized method were lower by 3 to $4 \%$ than those obtained by the certified method $(P \leq 0.03)$. Lactose values measured by HPLC were within 97 to $102 \%$ of the values obtained by the conventional enzymatic method (Table 1). Sample storage at $-20^{\circ} \mathrm{C}$ had no effect on mouse milk composition (Table 2).

Mouse milk composition had the lowest crude fat values at d 3 and greatest at $\mathrm{d} 14$ irrespective of mouse strain $(P<0.05$; Table 3$)$. In contrast, lactose concentration reached a maximum at lactation d 18 in DU6.
The lactose content was significantly greater in the CON strain compared with the DU6 strain at d 3. Between lactation $\mathrm{d} 3$ and 18 lactose concentration increased by $113 \%$ in the DU6 strain $(P<0.05$, Table 3$)$ suggesting greater milk yield in DU6 during late lactation, which was indirectly confirmed by milk volumes up to 3 times greater (overall mean: CON, $250 \mu \mathrm{L}$; DU6, $750 \mu \mathrm{L}$ ) milked from these larger animals.

Compared with manual milking, machine milking of all teats until emptiness yielded more milk per individual. It was previously shown that milk obtained from different teats of the same dam did not differ in composition (Rath and Thenen, 1979). Therefore, we should avoid pooling over lactation days and several individuals. In only 5 of 20 analytical samples in the CON strain was it necessary to combine milk of 2 dams; once, 3 dams were used to obtain suitable volumes.

For DM determination milk samples should be dried gently to avoid degradation of constituents, which are usually protected by adsorption to sea sand (Wiessmann and Nehring, 1951). In case of further use of the sample for $\mathrm{CP}$ determination, the drying temperature should not exceed $80^{\circ} \mathrm{C}$ (Knight et al., 1986). For small milk volumes of $10 \mu \mathrm{L}$, drying at $55^{\circ} \mathrm{C}$ for $5 \mathrm{~h}$ proved feasible. The $\mathrm{CP}$ values determined in other studies were greater (lactation d 9: 12.5 to $14.2 \%$; Ragueneau. 1987) or lower (lactation d 2 to $18: 6.7$ to $10.4 \%$; Riley et al., 2006) compared with our results (Table 3) and those of Knight et al. (1986) (10.2 to 12.5\%). This could be due to an effect of lactation day, the mouse strain, or be related to the use of different analytical methods. Colorimetric assays are not recommended for $\mathrm{CP}$ determination because interferences with other constitutes could alter the absorption of the protein dye complexes. In addition, a calibration with the true protein composition is necessary for a precise analysis. Therefore, mouse milk CP should be analyzed by nitrogen determination via elemental analyses requiring a milk sample volume as low as $10 \mu \mathrm{L}$, which is 5 to 10 times lower than reported for Kjeldahl procedure (Knight et al., 1986). Creamatocrit determination was applied for estimation of fat concentration in mouse milk (Knight et al., 1986), because low sample volumes were required (50 to $100 \mu \mathrm{L}$ ). Yet, in our hands this approach was unsatisfactory, because of incomplete lipid layer separation and inconsistent interfaces. Furthermore, validation with a reference method would be required to convert the creamatocrit into crude fat content. An alternative method for milk fat measurement is UV spectrophotometry requiring 30 to $60 \mu \mathrm{L}$ (Forcato et al., 2005). But dependence of the UV maximum on fat amount could influence values in samples with widely differing fat contents typical in mouse milk during lactation (Table 3). Additionally, calibration with 
Table 3. Mean milk composition of 2 mouse strains at different lactation days

\begin{tabular}{|c|c|c|c|c|c|c|c|}
\hline Item & \multicolumn{6}{|c|}{ Mouse strain } & SEM \\
\hline Lactation day & 3 & 14 & 18 & 3 & 14 & 18 & \\
\hline DM, \% & 33.6 & 43.8 & 41.5 & 35.6 & 45.5 & 43.0 & 2.51 \\
\hline $\mathrm{CP}, \%$ & 11.1 & 12.7 & 10.7 & 10.3 & 12.5 & 12.1 & 0.70 \\
\hline Crude fat, $\%$ & $17.1^{\mathrm{a}}$ & $29.0^{\mathrm{b}}$ & $26.5^{\mathrm{ab}}$ & $20.7^{\mathrm{a}}$ & $29.8^{\mathrm{b}}$ & $25.3^{\mathrm{ab}}$ & 2.43 \\
\hline
\end{tabular}

${ }^{\mathrm{a}-\mathrm{c}}$ Means within a row with different lowercase superscripts differ between lactation days within strains $(P<0.05)$.

${ }^{\mathrm{A}, \mathrm{B}}$ Means within a row with different uppercase superscripts differ between strains within lactation day $(P<0.05)$.

${ }^{1}$ Crude fat, $\mathrm{n}=5$.

a reference procedure is restricted by the availability of mouse milk. Because of these difficulties, the RöseGottlieb reference method established for fat content in cow milk was miniaturized for a volume of $100 \mu \mathrm{L}$ (Ragueneau, 1987: $200 \mu \mathrm{L}$ ). Commercial kits to assay the lactose concentration enzymatically usually require an aliquot of $100 \mu \mathrm{L}$ of milk. In contrast, only $20 \mu \mathrm{L}$ was needed for the HPLC protocol developed in this study. A further advantage is the reliable separation of lactose from its constitutive monomers.

Proper homogenization was the most important factor affecting mouse milk composition. Reproducibility of homogenization is known to be a factor in evaluating cow's milk composition. Adhesion effects of nonpolar substances at sample tube walls impede a complete mixing of all milk constituents and could decrease milk fat content (Table 1). Sample volumes considerably lower than $100 \mu \mathrm{L}$ hampered proper homogenization, and therefore, variation was high (Table 2: DM, d 14). It is recommended to start composition analysis in mouse milk with $\mathrm{DM} / \mathrm{CP}$ and lactose and perform the crude fat determination with the greatest sample volume (100 $\mu \mathrm{L}$ ) last. Altogether, a total volume of $140 \mu \mathrm{L}$ per individual mouse milk sample was sufficient for duplicate DM and CP determinations and single analyses for crude fat and lactose. Nevertheless, a volume of $200 \mu \mathrm{L}$ is recommended to allow appropriate homogenization, thereby increasing reproducibility and accuracy.

In agreement with other studies our data do not show differences in CP during lactation (Knight et al., 1986; Riley et al., 2006). Crude fat increased from d 3 to 14 and remained stable at d 18 (Table 3), which supports the previous work of Knight et al. (1986).Still, decrease of fat content from early to mid lactation was found by Ragueneau (1987). In contrast to the other components, lactose content increased with lactation day for DU6 mice, which supports earlier results (Riley et al. 2006).

The composition of mouse milk can vary considerably between mouse strains (Ragueneau, 1987), but variation can be high among individuals of the same strain on the same lactation day. For example, on d 14 crude fat ranged between 23.5 and $42.9 \%$ for the DU6 strain. In conclusion, in contrast to our hypothesis, milk composition differences were small between the 2 strains with the exception of lactose on $\mathrm{d} 3$.

\section{ACKNOWLEDGMENTS}

We thank A. Fischer for the development and construction of the milking machine, K. Karpati for technical assistance in nitrogen determination, and U. Lüdtke for performing the creamatocrit procedure (FBN Dummerstorf, Germany). The results reported herein have been obtained partially with financial support from the Commission of the European Community, within the FP 6 priority 5.4.3.1 Food quality and safety (EARNEST, Food-CT-2005-007036). This paper does not necessarily reflect the views of the Commission and in no way anticipates its future policy in this area.

\section{REFERENCES}

Bünger, L., A. Laidlaw, G. Bulfield, E. J. Eisen, J. F. Medrano, G. E. Bradford, F. Pircher, U. Renne, W. Schlote, and W. G. Hill. 2001. Inbred lines of mice derived from long-term growth selected lines: Unique resources for mapping growth genes. Mamm. Genome $12: 678-686$.

Forcato, D. O., M. P. Carmine, G. E. Echeverría, R. P. Pécora, and S. C. Kivatinitz. 2005. Milk fat content measurement by a simple UV spectrophotometric method: An alternative screening method. J. Dairy Sci. 88:478-481.

Karsten, U., M. Michalik, D. Michalik, and J. A. West. 2005. A new unusual low molecular weight carbohydrate in the red algal genus Hypoglossum (Delesseriaceae, Ceramiales) and its possible function as osmolyte. Planta 222:319-326.

Knight, C. H., E. Maltz, and A. H. Docherty. 1986. Milk yield and composition in mice: Effects of litter size and lactation number. Comp. Biochem. Physiol. 84A:127-133.

Ragueneau, S. 1987. Early development in mice: VI. Quantity and gross composition of milk in five inbred strains. Physiol. Behav. 40:431-435.

Rath, E. A., and S. W. Thenen. 1979. Use of tritiated water for measurement for 24-hour milk intake in suckling lean and genetically obese (ob/ob) mice. J. Nutr. 109:840-847. 
Renne, U., G. Dietl, M. Langhammer, C. Rehfeldt, K. Nürnberg, S. Kuhla, and L. Bünger. 2006. Phenotypic characterisation of extreme growth-selected mouse lines: An important prerequisite for future QTL analysis. Cent. Eur. J. Biol. 1:345-375.

Riley, L. G., M. Zubair, P. C. Thomson, M. Holt, S. P. Xavier, P. C. Wynn, and P. A. Sheehy. 2006. Lactational performance of Quackenbush Swiss line 5 mice. J. Anim. Sci. 84:2118-2125.
Rodgers, C. T. 1995. Practical aspects of milk collection in the rat. Lab. Anim. 29:450-455.

Wiessmann, H., and K. Nehring. 1951. Agrikulturchemisches Praktikum. Pages 159-179 in Quantitative Analyse. 2nd rev. ed. VII. Untersuchung der Milch. Verlag für Landwirtschaft, Gartenbau und Forstwesen, Berlin, Germany. 